\title{
EFFECT OF FARMYARD MANURE (FYM) DOSES AND DIFFERENT BIO-FERTILIZERS ON VEGETATIVE GROWTH, SEED YIELD AND ACTIVE CONSTITUENTS OF Plantago ovata FORSK PLANTS \\ Hamza, A. M.*; Hekmat Y. Massoud*; Malaka E. Eid**; M. R. Khater and Seham M. A. El-Gamal \\ *Veget. and Flori. Dept., Fac. of Agric., Mansoura Univ. \\ ${ }^{\star *}$ Hort. Res. Inst., Agric. Res. Center, Cairo.
}

\section{ABSTRACT}

The present investigation was carried out in the Experimental Station and Laboratory of the Vegetable Crops and Ornamental Plants Department, Faculty of Agriculture, Mansoura Univ., Egypt, during the two successive seasons of 2002/03 and 2003/04 to study the effect of farmyard manure (10, 20 and $30 \mathrm{~m}^{3} / \mathrm{fed}$.) and bio-fertilizers (Microbein, Phosphorein and Rhizobacterein) on Plantago ovata Forsk plants.

The results indicated that FYM doses had a positive effect on plant height, number of tillers and spikes, dry weight per plant, seed yield per plant and plot as well as mucilage content and percentage when compared with each other. The best results were of plants which received the medium FYM dose $\left(20 \mathrm{~m}^{3} / \mathrm{fed}\right)$.

The inoculating with Rhizobacterein bio-fertilizer gave the tallest plants, while the inoculating with Microbein gave the highest number of tillers and spikes, dry weight per plant, seed yield per plant and plot as well as mucilage content and percentage.

The combined treatment of the medium FYM dose and Rhizobacterein inoculating gave the tallest plants, while the combined treatment of the medium FYM dose and Microbein gave the highest number of tillers and spikes, dry weight per plant, seed yield per plant and plot as well as mucilage content and percentage. Also the combined treatment of the medium FYM dose and Phosphorein gave the heaviest 1000 seed weight.

\section{INTRODUCTION}

Plantago ovata Forsk (Isabgol) belongs to family Plantaginaceae is an annual herb and is the main source of isabgol seed and husk for use in medicine.

Isabgol seeds and husks are very rich in mucilage and have numerous pharmaceutical uses as, laxative drug (Marlett et al., 2000), as cosmetic products, e.g. face masks to soften the skin (Deters et al., 2005), as antiinflammatory activity in the intestine and beneficial effect in ulcerative colitis (Langmead and Rampton, 2001 and Rodriguez et al., 2003), beneficial effect in treatment of premenstrual constipation (Davies et al., 1998) and beneficial effects in male sterility (Jamwal et al., 1998).

The intensive use of chemical nutrition to plants in recent years resulted in environmental pollution and more human health problems.

Farmyard manure (FYM) added to soils to improve their physical and chemical properties. It increases the soil fertility by its composition from macro and micro elements, amino acids, organic acids, sugars and organic matter. Also it is a considerable useful habitat for several beneficial microorganisms. In the presence of organic materials the number of $\mathrm{N}_{2}$ fixes 
bacteria, mycorrhizae and phosphate solubilizing microorganisms increases in the soil as well as plant production (EL-Mahrouk, 2000).

Bhaskar et al. (2001) suggested that the application of farmyard manure (FYM) produced significantly higher number of shoots of geranium. The highest number of shoots and the highest fresh herbage yields were obtained with $30 \mathrm{t} F Y M / h a$.

EL-Ghawwas (2002) reported that farmyard manure at (18 $\mathrm{m}^{3} / \mathrm{fed}$.) was significantly improved plant height, number of fruits, seed weight per plant and the yield of volatile and fixed oils per plant and per plot in both seasons.

EL-Ghawwas et al. (2002) on fennel applied three levels of FYM (14, 21 and $28 \mathrm{~m}^{3} / \mathrm{fed}$.). They found that $28 \mathrm{~m}^{3} / \mathrm{fed}$. FYM significantly produced the tallest plants. The level $21 \mathrm{~m}^{3} / \mathrm{fed}$. FYM significantly produced the highest number of branches, the highest value of fruit yield per plant and plot and the highest volatile oil percentages.

Mohamed (2003) found that supplying periwinkle plants with $\quad 20-30 \mathrm{~m}^{3}$ /fed., turkey manure or 40-60 m/fed. cattle manure increased total alkaloids percentage in herb and roots, total alkaloids yield as well as $\mathrm{N}, \mathrm{P}, \mathrm{Zn}, \mathrm{Mn}$ and Fe contents in herb and roots. Also, total carbohydrates content in herb and roots was increased compared to those of the untreated plants.

Yuonis et al. (2004) mentioned that FYM significantly increased vegetative growth. Treating plants with different rates of FYM increased seed weight per plant and plot. Active ingredient of Ammi visnaga (Visnagin \& Khlein) significantly increased by increasing the rate of FYM.

Bio-fertilizers are the most reliable tools to reduce the rate of chemical fertilizers applied for medicinal plants production in all types of soil and hence decreasing environmental pollution (EL-Mahrouk, 2000).

The significant effect of bio-fertilizers may be due to the effect of different strain groups and nutrients mobilizing microorganisms which help in availability of metals and their forms in the composted material and increased levels of extractable minerals (EL-Kramany et al., 2000).

Abd EL-Latif (2002) showed that the mixture of $1 \mathrm{~kg} / \mathrm{fed}$. nitrobein +1 $\mathrm{kg} / \mathrm{fed}$. phosphorein with caraway seeds before sowing immediately gave the best results for the plant height, number of branches and fresh, dry weights per plant and the highest fruit yield .

Hafez (2003) stated on borage, that nitrobein (55\% Azotobacter chroococcum and $45 \%$ Azospirillum lipoferum containing one gram on $10^{7}$ cell) at $600 \mathrm{~g} / \mathrm{kg}$ seeds enhanced greatly plant height, number of branches, leaves fresh and dry weights and branches fresh and dry weights, compared with control.

Eisa (2004) reported that microbein and nitrobein bio-fertilizers increased the essential oil content per plant and oil yield per fed. of Salvia officinalis plants.

Massoud et al. (2004) showed that nitrobein plus phosphorein gave significant increase in plant height, number of branches, and plant fresh and dry weight of thyme plants.

Yousef (2005) concluded that the highest essential oil percentage of lemon balm was obtained when treated with $100 \mathrm{~kg} \mathrm{~N} / \mathrm{fed}$., and $4 \mathrm{~kg}$ nitrobein/ fed. 
The present work was planned to achieve the best growth, seed yield and mucilage content of isabgol through studying the optimum dose and best biofertilizer of farmyard manure.

\section{MATERIALS AND METHODS}

The present study was conducted during the two successive seasons of 2002/2003 and 2003/2004 at the Experimental Station and Laboratory of the Vegetable Crops and Ornamental Plants Dept., Faculty of Agriculture, Mansoura Univ., Egypt.

Seeds of isabgol (Plantago ovata Forsk), were secured from Müggenburg Firm, Hamburg, Germany and sown at the rate of $10 \mathrm{~kg} / \mathrm{fed}(5 \mathrm{~g} / \mathrm{plot})$ on October 15 in both seasons.

Field was ploughed and after the last ploughing, the field was divided into $2 \mathrm{~m}^{2}(1 \times 2 \mathrm{~m})$ plots and each plot contained 5 raws spaced at $15 \mathrm{~cm}$ apart.

All plots received chemical NPK fertilization as an activation dose at the rate of the quarter of the recommended rate of EL-Gamal, (2000).

In both seasons, NPK fertilizers were mixed and applied as one dose after one month from sowing.

The experimental field received farmyard manure (FYM) at three doses $\left(\mathrm{m}^{3} / \mathrm{feddan}\right)$ as $(10,20$ and 30$)$

FYM analyses in both seasons are shown in Table (1).

Table (1): Chemical analysis of the added FYM (farmyard manure) in both seasons (2002/03 and 2003/04).

\begin{tabular}{|l|c|c|}
\hline Properties \% & $\mathbf{2 0 0 2 / 2 0 0 3}$ & $\mathbf{2 0 0 3 / 2 0 0 4}$ \\
\hline Organic matter & 65.42 & 67.97 \\
\hline Total carbon & 38.03 & 39.52 \\
\hline Total nitrogen & 1.79 & 1.83 \\
\hline C/N ratio & $1: 21.25$ & $1: 21.59$ \\
\hline Total phosphate & 1.04 & 0.92 \\
\hline Total potassium & 0.98 & 0.89 \\
\hline pH (in 1: 5) & 8.19 & 8.17 \\
\hline
\end{tabular}

Bio-fertilizers were provided by the General Organization for Agriculture Equalization Fund (G.O.A.E.F.), Ministry of Agriculture, Egypt. The examined bio-fertilizers were Rhizobacterein, [it contains live cells of efficient bacteria strains for $\mathrm{N}$-fixation (Azotobacter sp.)], Phosphorein, [it contains live cells of efficient bacteria strains as phosphate solubilizing bacteria (Bacillus megaterium)] and Microbein, [it contains live cells of efficient bacteria strains for $\mathrm{N}$-fixation and phosphate solubilizing (Azotobacter sp., Azospirillum sp., Pseudomonas sp. and Bacillus sp.)] (plot/season).

All the bacterial growth media were used at a rate of $400 \mathrm{~g} / \mathrm{fed}(0.2 \mathrm{~g}$

\section{Treatments:}

1- The dose of $10 \mathrm{~m}^{3} \mathrm{FYM} / \mathrm{fed:}$

+0 bio-fertilizers as (control).

+ Rhizobacterein.

+ Phosphorein.

+ Microbein. 
Hamza, A. M. et al.

2- The dose of $20 \mathrm{~m}^{3} \mathrm{FYM} / \mathrm{fed}$ :

+0 bio-fertilizers as (control).

+ Rhizobacterein.

+ Phosphorein.

+ Microbein.

3- The dose of $30 \mathrm{~m}^{3} \mathrm{FYM} / \mathrm{fed}$ :

+0 bio-fertilizers as (control).

+ Rhizobacterein.

+ Phosphorein.

+ Microbein.

Data recorded:

A. Vegetative growth:

Thirty plants were chosen randomly for each character recorded after about 90 days from sowing as the following:

1. Plant height $(\mathrm{cm})$ :

2. Number of tillers per plant.

3. Number of spikes per plant.

4. Dry weight per plant $(\mathrm{g})$.

B. Seed yield (g):
1. per plant.
2. per plot.
3. Weight of 1000 seed.

C. Analysis:

1- Constituents of seeds:

Mucilage content (g per $10 \mathrm{~g}$ seeds) according to EL-Mahdy and ELSebaiy method (1984).

2- Chemical analysis of NPK : was determined according to Peter Burgski, (1968); Pregle, (1945); Jackson, (1967) and Black, (1965).

3- Experimental design and statistical analysis:

A factorial experiment in a randomized complete block design with 3 replicates was adapted, according to Cochran and Cox, (1957). The treatment means were compared using the least significant differences (L.S.D) at 0.05 procedures as mentioned by Gomez and Gomez, (1984).

Table (2): Mechanical and chemical analysis of experimental soil before the application of any fertilizers for the first seasons (2002/03).

\begin{tabular}{|c|c|c|c|c|c|c|}
\hline \multicolumn{2}{|c|}{$\begin{array}{c}\text { Mechanical analysis } \\
\%\end{array}$} & \multicolumn{3}{|c|}{ Chemical analysis } & \multicolumn{2}{|c|}{$\begin{array}{l}\text { Soluble cations and } \\
\text { anions } \mathrm{meq} / 100 \mathrm{~g} \text { soil }\end{array}$} \\
\hline Coarse sand & 0.98 & \multirow{3}{*}{$\begin{array}{c}\text { Available } \\
\text { (ppm) }\end{array}$} & $\mathbf{N}$ & 55 & \multicolumn{2}{|c|}{ Cation } \\
\hline Fine sand & 23.50 & & $\mathbf{P}$ & 2.8 & $\mathbf{C a}^{++}$ & 0.49 \\
\hline Silt & 30.96 & & $\mathrm{~K}$ & 590 & $\mathrm{Mg}^{++}$ & 0.37 \\
\hline Clay & 44.56 & \multicolumn{2}{|c|}{ Organic matter (\%) } & 1.15 & $\mathrm{Na}^{+}$ & 0.39 \\
\hline & & \multirow{2}{*}{\multicolumn{2}{|c|}{$\frac{\mathrm{EC}^{\star} \%}{\mathrm{pH}^{\star \star}}$}} & 0.08 & $\mathrm{~K}^{+}$ & 0.03 \\
\hline & & & & 8.25 & \multicolumn{2}{|c|}{ Anion } \\
\hline & & \multicolumn{2}{|c|}{$\mathrm{CaCO}_{3}$} & 0.84 & $\mathrm{CO}_{3}=$ & 0.02 \\
\hline & & & & & $\mathrm{HCO}_{3}{ }^{-}$ & 0.52 \\
\hline & & & & & $\mathrm{SO}_{4}=$ & 0.48 \\
\hline & & & & & $\mathrm{Cl}^{-}$ & 0.26 \\
\hline
\end{tabular}


Table (3): Mechanical and chemical analysis of the experimental field after the application of farmyard manure, bio and chemical fertilizers in the end of the first season (2003).

\begin{tabular}{|c|c|c|c|c|}
\hline \multirow{2}{*}{\multicolumn{2}{|c|}{ Properties }} & \multicolumn{3}{|c|}{$\mathrm{m}^{3} / \mathrm{fed}$} \\
\hline & & 10 & 20 & 30 \\
\hline \multicolumn{5}{|l|}{ Mechanical analysis (\%): } \\
\hline \multicolumn{2}{|l|}{ Coarse sand } & 0.74 & 1.19 & 1.30 \\
\hline \multicolumn{2}{|l|}{ Fine sand } & 21.26 & 19.15 & 18.94 \\
\hline \multicolumn{2}{|l|}{ Silt } & 29.72 & 29.49 & 24.75 \\
\hline \multicolumn{2}{|l|}{ Clay } & 48.28 & 51.50 & 58.38 \\
\hline \multicolumn{5}{|l|}{ Chemical analysis : } \\
\hline \multirow{3}{*}{ Available (ppm) } & $\mathbf{N}$ & 75 & 88 & 93 \\
\hline & $\mathbf{P}$ & 5.4 & 5.4 & 6.0 \\
\hline & $\mathbf{K}$ & 710 & 745 & 812 \\
\hline \multicolumn{2}{|c|}{ Organic matter (\%) } & 1.49 & 1.75 & 2.03 \\
\hline \multicolumn{2}{|c|}{$E^{*} \%$} & 0.07 & 0.08 & 0.09 \\
\hline \multicolumn{2}{|l|}{$\mathbf{p H}^{\star \star}$} & 8.03 & 7.89 & 7.90 \\
\hline \multicolumn{2}{|l|}{$\mathrm{CaCO}_{3}$} & 1.68 & 1.47 & 1.26 \\
\hline \multicolumn{5}{|c|}{ Soluble cations and anions (meq /100 g soil): } \\
\hline \multicolumn{5}{|c|}{ Cation } \\
\hline \multicolumn{2}{|l|}{$\mathrm{Ca}++$} & 0.38 & 0.44 & 0.42 \\
\hline \multicolumn{2}{|l|}{$\mathrm{Mg}++$} & 0.25 & 0.25 & 0.32 \\
\hline \multicolumn{2}{|l|}{$\mathrm{Na}+$} & 0.45 & 0.53 & 0.63 \\
\hline \multicolumn{2}{|l|}{$\mathbf{K +}$} & 0.04 & 0.06 & 0.07 \\
\hline \multicolumn{5}{|l|}{ Anion } \\
\hline \multicolumn{2}{|l|}{$\mathrm{CO}_{3}=$} & 0.00 & 0.00 & 0.04 \\
\hline \multicolumn{2}{|l|}{$\mathrm{HCO}_{3}^{-}$} & 0.42 & 0.40 & 0.33 \\
\hline \multicolumn{2}{|l|}{$\mathrm{SO}_{4}=$} & 0.41 & 0.52 & 0.55 \\
\hline \multicolumn{2}{|l|}{$\mathrm{Cl}^{-}$} & 0.29 & 0.36 & 0.56 \\
\hline
\end{tabular}

\section{RESULTS AND DISCUSSION}

\section{A. Effect of farmyard manure and bio-fertilizers on vegetative} growth of isabgol :

A.1. Plant height (cm):

A.1.1. Effect of farmyard manure (FYM) :

The results presented in Table (4) indicated the effect of FYM treatments on plant height of isabgol. The tallest plants $(36.05 \mathrm{~cm})$ were of plants fertilized with the medium FYM dose $\left(20 \mathrm{~m}^{3} / \mathrm{fed}\right)$.

The pre-mentioned increase in plant height was due to the organic manure which provided the plant with necessary demanded nutrients as well as improving the soil structure and drainage.

Similar results were obtained by Abd EL-Raouf (2001) on Ocimum basilicum and EL-Ghawwas (2002) on Nigella sativa.

\section{A.1.2. Effect of bio-fertilizers:}

The tallest plants were those inoculated by Rhizobacterein biofertilizer $(34.91$ and $35.68 \mathrm{~cm})$, but the shortest plants $(33.09$ and $33.89 \mathrm{~cm})$ were of control plants in the two seasons, respectively (Table 4).

Supplying isabgol plants with Microbein gave increases in plant height, but less than Rhizobacterein (34.42 and $35.51 \mathrm{~cm}$ ). 
Hamza, A. M. et al.

The plant height increase may be due to that biofertilizers (Rhizobacterein and Microbein) supplied isabgol with nitrogen which is a precursor of protein synthesis and a vacuolar osmoticum. The osmotic compounds in the cell sap are important in order to allow cell enlargement.

The above mentioned results followed the same manner as those obtained by Ibrahim (2000) on Ammi visnaga and Foeniculum vulgare, Attia and Saad (2001) on Catharanthus roseus and Sakr (2005) on Cassia acutifolia found that bio-fertilizers caused a significant increase in plant height.

Table (4) Effect of farmyard manure (FYM) and bio-fertilizers on the plant height $(\mathrm{cm})$ of Plantago ovata Forsk during the two seasons of 2002/2003 and 2003/2004.

\begin{tabular}{|c|c|c|}
\hline \multirow[b]{2}{*}{ Treatments } & \multicolumn{2}{|c|}{ Plant height (cm ) } \\
\hline & $2002 / 2003$ & $2003 / 2004$ \\
\hline \multicolumn{3}{|c|}{ FYM doses $\left(\mathrm{m}^{3} / \mathrm{fed}\right)$} \\
\hline 10 & 31.28 & 32.02 \\
\hline 20 & 36.05 & 36.53 \\
\hline 30 & 34.77 & 35.87 \\
\hline L.S.D at $5 \%$ & 0.16 & 0.14 \\
\hline \multicolumn{3}{|l|}{ Bio-fertilizers } \\
\hline Control & 33.09 & 33.89 \\
\hline Microbein & 34.42 & 35.51 \\
\hline Phosphorein & 33.71 & 34.66 \\
\hline Rhizobacterein & 34.91 & 35.68 \\
\hline L.S.D at $5 \%$ & 0.19 & 0.16 \\
\hline
\end{tabular}

\section{A.1.3. Effect of interaction between FYM and bio-fertilizers:}

Table (5) showed that the plants fertilized with the medium FYM dose and inoculated with Rhizobacterein gave the tallest plants (37.83 and 39.86 $\mathrm{cm}$ ) while the shortest plants were of the low biofertilizers (control) (30.68 and $31.26 \mathrm{~cm}$ ) in the two seasons, respectively.

These results agreed in general, with the findings reported by Hafez (2003) on borage and Sakr (2005) on senna, showing the positive effect of either organic or biofertilization in this respect.

Table (5): Effect of interaction between farmyard manure (FYM) and biofertilizers on the plant height $(\mathrm{cm})$ of Plantago ovata Forsk during the two seasons of 2002/03 and 2003/04.

\begin{tabular}{|c|c|c|c|}
\hline \multirow{2}{*}{\multicolumn{2}{|c|}{$\begin{array}{c}\text { Treatments FYM } \\
\left(\mathbf{m}^{3} / \mathrm{fed}\right)\end{array}$}} & \multicolumn{2}{|c|}{ Plant height $(\mathrm{cm})$} \\
\hline & & $2002 / 2003$ & $2003 / 2004$ \\
\hline \multirow{4}{*}{10} & Control & 30.68 & 31.26 \\
\hline & Microbein & 31.79 & 32.88 \\
\hline & Phosphorein & 30.97 & 31.73 \\
\hline & Rhizobacterein & 31.96 & 32.96 \\
\hline \multirow{4}{*}{20} & Control & 34.85 & 35.39 \\
\hline & Microbein & 37.19 & 38.08 \\
\hline & Phosphorein & 35.72 & 36.59 \\
\hline & Rhizobacterein & 37.83 & 39.86 \\
\hline \multirow{5}{*}{30} & Control & 33.75 & 35.01 \\
\hline & Microbein & 35.77 & 36.35 \\
\hline & Phosphorein & 34.43 & 35.61 \\
\hline & Rhizobacterein & 36.13 & 37.46 \\
\hline & S.D at $5 \%$ & N.S & N.S \\
\hline
\end{tabular}


A.2. Number of tillers and spikes per plant:

\section{A.2.1.Effect of FYM doses:}

Data presented in Table (6) detected that the FYM fertilization doses promoted the growth of tillers and spikes per plant during both growing seasons. The largest number of tillers (4.43 and 6.83) and spikes (13.73 and 15.79) per plant were of plants fertilized with the medium FYM dose, but the least number of tillers (2.40 and 3.63) and spikes (7.33 and 9.91) per plant were of plants fertilized with the low FYM dose in the two seasons, respectively. Farmyard manure was important in maintenance of soil fertility and structure.

EL-Ghawwas et al. (2002) on fennel and Abd EL-Latif (2006) on sage who found that organic manure at $20 \mathrm{~m}^{3} / \mathrm{fed}$ gave the best results in plant growth, dry weight, dry yield and essential oil yield.

Table (6): Effect of farmyard manure (FYM) and bio-fertilizers on the number of tillers and the number of spikes per plant of Plantago ovata Forsk during the two seasons of 2002/03 and 2003/04.

\begin{tabular}{|c|c|c|c|c|}
\hline \multirow{2}{*}{$\begin{array}{ll}\text { Treatments } & \text { Characters } \\
\end{array}$} & \multicolumn{2}{|c|}{ Number of tillers /plant } & \multicolumn{2}{|c|}{ Number of spikes /plant } \\
\hline & $2002 / 2003$ & $2003 / 2004$ & $2002 / 2003$ & $2003 / 2004$ \\
\hline \multicolumn{5}{|l|}{ FYM doses $\left(\mathrm{m}^{3} / \mathrm{fed}\right)$} \\
\hline 10 & 2.40 & 3.63 & 7.33 & 9.91 \\
\hline 20 & 4.43 & 6.83 & 13.73 & 15.79 \\
\hline 30 & 3.89 & 5.67 & 11.89 & 13.72 \\
\hline L.S.D at $5 \%$ & 0.14 & 0.16 & 0.22 & 0.46 \\
\hline \multicolumn{5}{|l|}{ Bio-fertilizers } \\
\hline Control & 3.04 & 4.54 & 8.94 & 11.28 \\
\hline Microbein & 4.17 & 6.24 & 13.08 & 15.42 \\
\hline Phosphorein & 3.32 & 4.99 & 10.19 & 11.98 \\
\hline hizobacterein & 3.77 & 5.73 & 11.73 & 13.87 \\
\hline L.S.D at $5 \%$ & 0.16 & 0.18 & 0.26 & 0.53 \\
\hline
\end{tabular}

\section{A.2.2. Effect of bio-fertilizers:}

It was obvious from data in Table (6) that biofertilizer increased number of tillers and spikes per plant in the two seasons as compared with the untreated ones. The largest number of tillers (4.17 and 6.24) and spikes (13.08 and 15.42) per plant were of plants inoculated by Microbein followed by Rhizobacterein inoculating (3.77 and 5.73) tillers and spikes (11.73 and 13.87) per plant. The least number of tillers (3.04 and 4.54) and (8.94 and $11.28)$ spikes per plant were of the untreated plants. The differences were significant in both seasons when the biofertilizers were compared with each other the control.

Herein results followed the same manner as those obtained by Ibrahim (2000) on Ammi visnaga and Foeniculum vulgare, Mahfouz (2003) on marjoram, Yadav et al. (2004) on isabgol and Sakr (2005) on senna.

\section{A.2.3. Effect of interaction between FYM doses and bio-fertilizers:}

The plants fertilized with the medium FYM dose and inoculated with Microbein had the largest number of tillers (5.23 and 7.93) and spikes (16.47 and 19.10) per plant, while the least number of tillers (2.03 and 2.86) and spikes (5.30 and 7.72) per plant were of plants which received the low FYM dose and 0 bio-fertilizer, in the two seasons, respectively (Table 7). 
Hamza, A. M. et al.

Table (7): Effect of interaction between FYM and bio-fertilizers on the No. of tillers and spikes per plant of Plantago ovata Forsk during the two seasons of 2002/03 and 2003/04.

\begin{tabular}{|c|c|c|c|c|c|}
\hline \multirow{2}{*}{\multicolumn{2}{|c|}{$\begin{array}{ll}\text { Treatments } & \text { Characters }\end{array}$}} & \multicolumn{2}{|c|}{ No. of tillers /plant } & \multicolumn{2}{|c|}{ No. of spikes /plant } \\
\hline & & $2002 / 2003$ & $2003 / 2004$ & $2002 / 2003$ & $2003 / 2004$ \\
\hline \multicolumn{6}{|c|}{ FYM $\left(m^{3} /\right.$ fed $)$} \\
\hline \multirow{4}{*}{10} & Control & 2.03 & 2.86 & 5.30 & 7.72 \\
\hline & Microbein & 2.87 & 4.43 & 9.17 & 11.53 \\
\hline & Phosphorein & 2.17 & 3.33 & 6.60 & 8.93 \\
\hline & Rhizobacterein & 2.53 & 3.90 & 8.26 & 11.43 \\
\hline \multirow{4}{*}{20} & Control & 3.71 & 5.73 & 11.30 & 13.66 \\
\hline & Microbein & 5.23 & 7.93 & 16.47 & 19.10 \\
\hline & Phosphorein & 4.13 & 6.36 & 12.63 & 14.33 \\
\hline & Rhizobacterein & 4.63 & 7.30 & 14.53 & 16.06 \\
\hline \multirow{4}{*}{30} & Control & 3.36 & 5.03 & 10.23 & 11.46 \\
\hline & Microbein & 4.40 & 6.02 & 13.60 & 15.63 \\
\hline & Phosphorein & 3.68 & 5.23 & 10.93 & 12.67 \\
\hline & Rhizobacterein & 4.13 & 6.00 & 12.40 & 14.10 \\
\hline & L.S.D at $5 \%$ & N.S & N.S & 0.44 & 0.92 \\
\hline
\end{tabular}

\section{A.3. Plant dry weight (g):}

\section{A.3.1 Effect of FYM :}

The data in Table (8) revealed that the different FYM doses gave variable results for plant dry weight $(\mathrm{g})$ in both seasons. The heaviest plant dry weight (4.28 and $4.70 \mathrm{~g} /$ plant) was of plants which received medium FYM dose, while the lightest plant dry weights (3.47 and $3.87 \mathrm{~g} / \mathrm{plant}$ ) were of plants that received low FYM dose. The differences were significantly between FYM doses in both seasons.

Table (8): Effect of farmyard manure (FYM) and bio-fertilizers on the plant dry weight (g) of Plantago ovata Forsk during the two seasons of 2002/03 and 2003/04.

\begin{tabular}{|c|c|c|}
\hline \multirow[t]{2}{*}{ Treatments } & \multicolumn{2}{|c|}{ Plant dry weight (g) } \\
\hline & $2002 / 2003$ & $2003 / 2004$ \\
\hline \multicolumn{3}{|l|}{ FYM rates $\left(\mathrm{m}^{3} / \mathrm{fed}\right)$} \\
\hline 10 & 3.47 & 3.87 \\
\hline 20 & 4.28 & 4.70 \\
\hline 30 & 4.10 & 4.50 \\
\hline L.S.D at $5 \%$ & 0.04 & 0.06 \\
\hline \multicolumn{3}{|l|}{ Bio-fertilizers } \\
\hline Control & 3.68 & 3.92 \\
\hline Microbein & 4.40 & 4.67 \\
\hline Phosphorein & 3.88 & 4.18 \\
\hline Rhizobacterein & 4.06 & 4.45 \\
\hline L.S.D at $5 \%$ & 0.05 & 0.07 \\
\hline
\end{tabular}

The obtained results agreed with those obtained by Sakr (2005) on senna and Abd EL-Latif (2006) on sage.

\section{A.3.2. Effect of bio-fertilizers:}

The heaviest plant dry weights (4.40 and $4.67 \mathrm{~g} /$ plant) were of plants inoculated with Microbein biofertilizer, but the lightest plant dry weights (3.68 and $3.92 \mathrm{~g} /$ plant) were of uninoculated plants (control) in the two seasons, respectively (Table 8 ). 
The bio-fertilizers supplied plants with $\mathrm{N}$ and $\mathrm{P}$ which might play a direct role in plant metabolism through activating the photosynthesis process as well as accumulation of their products in plant organs resulting in more plant growth. In other words, they enable the plant to build up organic materials (Mengel and Kirkby, 1982). Also, nitrogen increase growth and this in turn increase the carbohydrate formed by plant, thus dry weight increase.

The obtained results agreed with those obtained by Eid and ELGhawwas (2002) on marjoram, Hafez (2003) on borage, EL-Fawakhry and EL-Tayeb (2004) on Euphorbia pulcherrima.

A.3.3. Effect of interaction between FYM doses and different biofertilizers:

The heaviest plant dry weight was obtained when isabgol plants were applied with medium FYM dose and inoculated with Microbein biofertilizer (4.89 and $5.22 \mathrm{gm} /$ plant) while the least plant dry weight (3.22 and 3.58 $\mathrm{gm} /$ plant) was obtained when isabgol plants were supplied with low FYM dose and no biofertilizer applied in the two seasons, respectively (Table 9).

Table (9): Effect of interaction between farmyard manure (FYM) and biofertilizers on the plant dry weight (g) of Plantago ovata Forsk during the two seasons of 2002/03 and 2003/04.

\begin{tabular}{|c|c|c|c|}
\hline \multirow{2}{*}{\multicolumn{2}{|c|}{ Treatments }} & \multicolumn{2}{|c|}{ Plant dry weight (g) } \\
\hline & & $2002 / 2003$ & $2003 / 2004$ \\
\hline \multicolumn{4}{|c|}{ FYM $\left(\mathbf{m}^{3} /\right.$ fed $)$} \\
\hline \multirow{4}{*}{10} & Control & 3.22 & 3.58 \\
\hline & Microbein & 3.77 & 4.25 \\
\hline & Phosphorein & 3.34 & 3.73 \\
\hline & Rhizobacterein & 3.69 & 4.03 \\
\hline \multirow{4}{*}{20} & Control & 3.97 & 4.04 \\
\hline & Microbein & 4.89 & 5.22 \\
\hline & Phosphorein & 4.05 & 4.24 \\
\hline & Rhizobacterein & 4.59 & 4.99 \\
\hline \multirow{4}{*}{30} & Control & 3.85 & 4.00 \\
\hline & Microbein & 4.55 & 4.89 \\
\hline & Phosphorein & 3.95 & 4.28 \\
\hline & Rhizobacterein & 4.35 & 4.74 \\
\hline & L.S.D at $5 \%$ & 0.07 & 0.11 \\
\hline
\end{tabular}

B. Effect of farmyard manure (FYM) and bio-fertilizers on seed yield of isabgol:

B.1. Seed yield per plant and plot $(\mathrm{g})$ :

B.1.1. Effect of FYM doses:

Data of seed yield per plant as affected by FYM doses were presented in Table (10). The heaviest seed yield per plant $(4.92 \mathrm{~g})$ and plot $(182.16 \mathrm{~g})$ were obtained from plants fertilized by the medium FYM dose, while the lightest seed yield per plant $(3.48 \mathrm{~g})$ and plot $(127.80 \mathrm{~g})$ were of plants received the low FYM dose in the first season. The results of the second season followed the same trend.

The differences between FYM doses were significant when compared with each other in both seasons.

The obtained results were in line with those of EL-Ghawwas (2002) on Nigella sativa and Younis et al. (2004) on Ammi visnaga. 
Table (10): Effect of farmyard manure (FYM) and biofertilizers on the seed yield per plant and plot $(\mathrm{g})$ of Plantago ovata Forsk during the two seasons of 2002/03 and 2003/04.

\begin{tabular}{|c|c|c|c|c|}
\hline \multirow{2}{*}{ Characters } & \multicolumn{4}{|c|}{ Seed yield (g) per } \\
\cline { 2 - 5 } Treatments & \multicolumn{3}{|c|}{ plant } & \multicolumn{3}{c|}{ plot } \\
\cline { 2 - 5 } FYM rates(m $\mathbf{3} / \mathbf{f e d})$ & $\mathbf{2 0 0 2 / 2 0 0 3}$ & $\mathbf{2 0 0 3 / 2 0 0 4}$ & $\mathbf{2 0 0 2 / 2 0 0 3}$ & $\mathbf{2 0 0 3 / 2 0 0 4}$ \\
\hline $\mathbf{1 0}$ & 3.48 & 3.85 & 127.80 & 155.56 \\
\hline $\mathbf{2 0}$ & 4.92 & 5.69 & 182.16 & 237.18 \\
\hline $\mathbf{3 0}$ & 4.34 & 5.54 & 171.33 & 221.42 \\
\hline L.S.D at 5\% & 0.05 & 0.02 & 2.98 & 2.86 \\
\hline Bio-fertilizers & 3.70 & 4.00 & 139.91 & 168.40 \\
\hline Control & 4.77 & 5.51 & 188.91 & 225.03 \\
\hline Microbein & 4.00 & 4.69 & 160.17 & 189.33 \\
\hline Phosphorein & 4.42 & 5.07 & 176.05 & 200.12 \\
\hline Rhizobacterein & 0.05 & 0.03 & 3.45 & 3.30 \\
\hline L.S.D at 5 \% & \multicolumn{3}{|c}{} \\
\hline
\end{tabular}

\section{B.1.2. Effect of bio-fertilizers:}

Dealing with the effect of different biofertilizers on seed yield per plant and plot in both seasons was shown in Table (10).

The heaviest seed yield per plant $(4.77$ and $5.51 \mathrm{~g})$ and plot $(188.91$ and $225.03 \mathrm{~g}$ ) were of plants inoculated with Microbein bio-fertilizer followed by the inoculating with Rhizobacterein bio-fertilizer (4.42 and $5.07 \mathrm{~g} / \mathrm{plant})$ and plot (176.05 and $200.12 \mathrm{~g} /$ plot), while the lightest seed yield per plant $(3.70$ and $4.00 \mathrm{~g})$ and plot $(139.91$ and $168.40 \mathrm{~g})$ were of control plants in the two seasons, respectively.

The increase in seed yield per plant with bio-fertilizers may be due to the action of the bacteria in the biofertilizers resulting in an increasing effect on the vegetative growth and shortening the period required to reach flowering, thus increasing seed production (Sakr, 2005).

Moreover, the above results were in agreement with those obtained by Kandeel et al. (2001) on Foeniculum vulgare, Nofal et al. (2001) on Ammi visnaga and Abdel-Kader and Ghaly (2003) on coriander.

\section{B.1.3. Effect of interaction between FYM and bio-fertilizers:}

Results in Table (11) indicated that the seed yield per plant and plot were affected significantly as a result of interaction between FYM doses and the different bio-fertilizers. The heaviest seed yield per plant which reached $(5.14$ and $5.90 \mathrm{~g})$ and plot $(200.90$ and $242.21 \mathrm{~g})$ were of plants that received the medium FYM dose and inoculated with Microbein.

The tremendous increases may be due to the release of available nutrients from organic manure when combined with the favourable effect of bio-fertilization at the same time.

\section{B.2. 1000 seed weight $(\mathrm{g})$ :}

\section{B.2.1. Effect of farmyard manure (FYM) :}

The heaviest 1000 seed weight $(1.83 \mathrm{~g} / 1000 \mathrm{seed})$ was obtained from plants fertilized by the medium FYM dose, while the lightest 1000 seed weight $(1.45 \mathrm{~g} / 1000 \mathrm{seed})$ was obtained from plants fertilized by the low FYM dose in the first season. The results of the second season followed the 
same trend. The differences were significant between all FYM doses in both seasons (Table 12).

Table (11): Effect of interaction between farmyard manure (FYM) and bio-fertilizers on the seed yield per plant and plot $(\mathrm{g})$ of Plantago ovata Forsk during the two seasons of 2002/03 and 2003/04.

\begin{tabular}{|c|c|c|c|c|c|}
\hline \multirow{3}{*}{\multicolumn{2}{|c|}{ Treatments }} & \multicolumn{4}{|c|}{ Seed yield (g) / } \\
\hline & & \multicolumn{2}{|c|}{ plant } & \multicolumn{2}{|c|}{ plot } \\
\hline & & $2002 / 2003$ & $2003 / 2004$ & $2002 / 2003$ & $2003 / 2004$ \\
\hline \multicolumn{6}{|c|}{ FYM $\left(\mathrm{m}^{3} / \mathrm{fed}\right)$} \\
\hline \multirow{4}{*}{10} & Control & 3.01 & 3.27 & 116.95 & 125.59 \\
\hline & Microbein & 3.70 & 4.21 & 149.92 & 175.76 \\
\hline & Phosphorein & 3.27 & 3.75 & 123.87 & 152.27 \\
\hline & Rhizobacterein & 3.56 & 4.07 & 138.45 & 167.64 \\
\hline \multirow{4}{*}{20} & Control & 3.91 & 4.29 & 175.07 & 198.78 \\
\hline & Microbein & 5.14 & 5.90 & 200.90 & 242.21 \\
\hline & Phosphorein & 4.16 & 4.73 & 188.17 & 212.08 \\
\hline & Rhizobacterein & 4.97 & 5.81 & 194.49 & 230.63 \\
\hline \multirow{4}{*}{30} & Control & 3.86 & 4.09 & 167.72 & 179.83 \\
\hline & Microbein & 4.87 & 5.80 & 195.90 & 235.11 \\
\hline & Phosphorein & 4.05 & 5.57 & 177.48 & 200.64 \\
\hline & Rhizobacterein & 4.69 & 5.72 & 186.22 & 221.09 \\
\hline \multicolumn{2}{|c|}{ L.S.D at $5 \%$} & 0.09 & 0.04 & 5.97 & 5.72 \\
\hline
\end{tabular}

Table (12): Effect of farmyard manure (FYM) and bio-fertilizers on the 1000 seed weight $(\mathrm{g})$ of Plantago ovata Forsk during the two seasons of 2002/03 and 2003/04.

\begin{tabular}{|c|c|c|}
\hline \multirow{2}{*}{ Treatments } & \multicolumn{2}{|c|}{1000 seed weight $(g)$} \\
\hline & $2002 / 2003$ & $2003 / 2004$ \\
\hline \multicolumn{3}{|l|}{ FYM rates $\left(\mathbf{m}^{3} / \mathrm{fed}\right)$} \\
\hline 10 & 1.45 & 1.51 \\
\hline 20 & 1.83 & 1.90 \\
\hline 30 & 1.81 & 1.85 \\
\hline L.S.D at $5 \%$ & 0.01 & 0.02 \\
\hline \multicolumn{3}{|l|}{ Bio-fertilizers } \\
\hline Control & 1.62 & 1.66 \\
\hline Microbein & 1.82 & 1.88 \\
\hline Phosphorein & 1.85 & 1.94 \\
\hline Rhizobacterein & 1.71 & 1.80 \\
\hline L.S.D at $5 \%$ & 0.03 & 0.02 \\
\hline
\end{tabular}

These results were in agreement with those obtained by Ahmed (2005) on okra, who found that applying okra with $20 \mathrm{~m}^{3} / \mathrm{fed} \mathrm{FYM} \mathrm{gave} \mathrm{the}$ best growth, seed yield per plant and seed weight per pod and 1000 seed weight.

B.2.2. Effect of bio-fertilizers:

Data presented in Table (12) showed that, the heaviest 1000 seed weight (1.85 and $1.94 \mathrm{~g} / 1000$ seed) was of plants inoculated with Phosphorein bio-fertilizer, but the lightest 1000 seed weight $(1.62$ and $1.66 \mathrm{~g}$ $/ 1000$ seed) was of control plants in the two seasons, respectively. 
Hamza, A. M. et al.

The Microbein followed Phosphorein in affecting seed weight (1.82 and $1.88 \mathrm{~g} / 1000 \mathrm{seed}$ ) in both seasons. These results may be due to that phosphate solubilizing might encourage plant to stimulate flowering and improving quality of seeds.

The obtained results were in agreement with those obtained by Tomar et al. (1996) on Cicer arietinum.

B.2.3. Effect of interaction between FYM doses and different biofertilizers:

The heaviest 1000 seed weight was of plants fertilized with the medium FYM dose and inoculated with Phosphorein biofertilizer (1.90 and $1.98 \mathrm{~g} / 1000$ seed). On the other hand, the lightest 1000 seed weight was of plants received the low FYM dose and no bio-fertilization in the two seasons, respectively (Table 13).

Table (13): Effect of interaction between farmyard manure (FYM) and bio-fertilizers on the 1000 seed weight (g) of Plantago ovata Forsk during the two seasons of 2002/03 and 2003/04.

\begin{tabular}{|c|c|c|c|}
\hline & \multicolumn{2}{|c|}{1000 seed weight $(\mathrm{g})$} \\
\hline \multirow{2}{*}{\multicolumn{4}{|c|}{$\begin{array}{l}\text { Treatments } \\
\text { FYM }\left(\mathrm{m}^{3} / \mathrm{fed}\right)\end{array}$}} \\
\hline & & & \\
\hline \multirow{4}{*}{10} & Control & 1.44 & 1.49 \\
\hline & Microbein & 1.79 & 1.83 \\
\hline & Phosphorein & 1.80 & 1.86 \\
\hline & Rhizobacterein & 1.64 & 1.68 \\
\hline \multirow{4}{*}{20} & Control & 1.71 & 1.80 \\
\hline & Microbein & 1.84 & 1.92 \\
\hline & Phosphorein & 1.90 & 1.98 \\
\hline & Rhizobacterein & 1.79 & 1.84 \\
\hline \multirow{5}{*}{30} & Control & 1.65 & 1.78 \\
\hline & Microbein & 1.82 & 1.87 \\
\hline & Phosphorein & 1.85 & 1.93 \\
\hline & Rhizobacterein & 1.75 & 1.82 \\
\hline & L.S.D at $5 \%$ & N.S & N.S \\
\hline
\end{tabular}

C. Effect of farmyard manure (FYM) and bio-fertilizers on isabgol constituents:

C.1. Mucilage content in seeds:

C.1.1. Effect of farmyard manure (FYM) :

The highest significantly mucilage content and percentage [3.48 g $(34.8 \%)]$ were of plants which received the medium FYM dose when compared with the lowest values attained of $[2.97 \mathrm{~g}(29.7 \%)]$ of plants that received the low FYM dose in the first season (Table, 13).

The results of mucilage content in the second season followed the same trend. The positive responses induced by suitable farmyard manure dose suggest the possibility of the promotive effects on photosynthetic activity and consequently photosynthetic products, mainly carbohydrates.

The obtained results were agreed with those of Yadav et al. (2004) on isabgol and Ahmed (2005) on okra. 


\section{C.1.2. Effect of different bio-fertilizers:}

The highest mucilage content and percentage [3.42 $\mathrm{g}(34.2 \%)]$ were of plants inoculated with Microbein biofertilizer followed by the inoculating with Phosphorein biofertilizer, then inoculating with Rhizobacterein. The lowest mucilage content and percentage in this respect were of control plants $[3.07 \mathrm{~g}(30.7 \%)]$ in the first season. The second season results followed the same trend of the first season results (Table 14).

Table (14): Effect of farmyard manure (FYM) and bio-fertilizers on the mucilage content $(\mathrm{g})$ and percent in seeds of Plantago ovata Forsk during the two seasons of 2002/03 and 2003/04.

\begin{tabular}{|c|c|c|c|c|}
\hline \multirow{3}{*}{ Treatments } & \multicolumn{4}{|c|}{ Mucilage } \\
\hline & \multicolumn{2}{|c|}{ content $(\mathrm{g}) / 10 \mathrm{~g}$ seeds } & \multicolumn{2}{|c|}{$(\%)$} \\
\hline & $2002 / 2003$ & $2003 / 2004$ & $2002 / 2003$ & $2003 / 2004$ \\
\hline \multicolumn{5}{|l|}{ FYM rates $\left(\mathrm{m}^{3} / \mathrm{fed}\right)$} \\
\hline 10 & 2.97 & 3.10 & 29.7 & 31.0 \\
\hline 20 & 3.48 & 3.51 & 34.8 & 35.1 \\
\hline 30 & 3.32 & 3.40 & 33.2 & 34.0 \\
\hline L.S.D at $5 \%$ & 0.02 & 0.01 & & \\
\hline \multicolumn{5}{|l|}{ Bio-fertilizers } \\
\hline Control & 3.07 & 3.10 & 30.7 & 31.0 \\
\hline Microbein & 3.42 & 3.50 & 34.2 & 35.0 \\
\hline hosphorein & 3.23 & 3.36 & 32.3 & 33.6 \\
\hline Rhizobacterein & 3.18 & 3.22 & 31.8 & 32.2 \\
\hline L.S.D at $5 \%$ & 0.02 & 0.02 & & \\
\hline
\end{tabular}

The obtained results were in agreement with those obtained by Maheshwari et al. (2003) on blond psyllium and Ahmed (2005) on okra.

\section{C.1.3. Effect of interaction between FYM and bio-fertilizers:}

The highest values [3.43 g $(34.3 \%)$ and $3.69 \mathrm{~g}(36.9 \%)]$ were obtained from plants fertilized with the medium FYM dose and inoculated with Microbein biofertilizer, followed by plants fertilized with the medium FYM dose and inoculated with Phosphorein [3.35 g (33.5\%) and $3.59 \mathrm{~g} \mathrm{(35.9 \% )],} \mathrm{while}$ the lowest values were obtained from plants received the low FYM dose and not treated with biofertilizers [2.86 $\mathrm{g}(28.6 \%)$ and $3.01 \mathrm{~g}(30.1 \%)]$ in both seasons, respectively (Table 15).

\section{C.2. $\mathrm{N}, \mathrm{P}$ and $\mathrm{K}$ percentages:}

\section{C.2.1. Effect of FYM doses:}

NPK percentage in the dry leaves of isabgol (Table 16) revealed that the application of FYM doses gave significant differences in both seasons when compared each other. The highest FYM dose gave the highest nitrogen $(1.67 \%)$, phosphorus $(0.35 \%)$ and potassium (2.36 \%) compared to the medium and low dose in the first season. The results of nitrogen, phosphorus and potassium percentages in the second season followed the same trend. 
Hamza, A. M. et al.

Table (15): Effect of interaction between farmyard manure (FYM) and bio-fertilizers on the mucilage content $(\mathrm{g})$ and percent in seeds of Plantago ovata Forsk during the two seasons of 2002/03 and 2003/04.

\begin{tabular}{|c|c|c|c|c|c|}
\hline \multirow{3}{*}{\multicolumn{2}{|c|}{ Treatments }} & \multicolumn{4}{|c|}{ Mucilage } \\
\hline & & \multicolumn{2}{|c|}{ content $(\mathrm{g}) / 10 \mathrm{~g}$ seeds } & \multicolumn{2}{|c|}{$(\%)$} \\
\hline & & $2002 / 2003$ & $2003 / 2004$ & $2002 / 2003$ & $2003 / 2004$ \\
\hline \multicolumn{6}{|c|}{ FYM $\left(\mathrm{m}^{3} / \mathrm{fed}\right)$} \\
\hline \multirow{4}{*}{10} & Control & 2.86 & 3.01 & 28.6 & 30.1 \\
\hline & Microbein & 3.16 & 3.29 & 31.6 & 32.9 \\
\hline & Phosphorein & 3.09 & 3.26 & 30.9 & 32.6 \\
\hline & Rhizobacterein & 2.99 & 3.14 & 29.9 & 31.4 \\
\hline \multirow{4}{*}{20} & Control & 3.19 & 3.21 & 31.9 & 32.1 \\
\hline & Microbein & 3.43 & 3.69 & 34.3 & 36.9 \\
\hline & Phosphorein & 3.35 & 3.59 & 33.5 & 35.9 \\
\hline & Rhizobacterein & 3.20 & 3.27 & 32.0 & 32.7 \\
\hline \multirow{5}{*}{30} & Control & 3.07 & 3.19 & 30.7 & 31.9 \\
\hline & Microbein & 3.40 & 3.48 & 34.0 & 34.8 \\
\hline & Phosphorein & 3.28 & 3.39 & 32.8 & 33.9 \\
\hline & Rhizobacterein & 3.14 & 3.24 & 31.4 & 32.4 \\
\hline & L.S.D at $5 \%$ & 0.03 & 0.03 & & \\
\hline
\end{tabular}

Table (16): Effect of farmyard manure (FYM) and biofertilizers on the dry leaves NPK (\%) of Plantago ovata Forsk during the two seasons of 2002/03 and 2003/04.

\begin{tabular}{|c|c|c|c|c|c|c|}
\hline \multirow{2}{*}{ Characters } & \multicolumn{2}{|c|}{$\mathbf{N}(\%)$} & \multicolumn{2}{|c|}{$\mathbf{P}(\%)$} & \multicolumn{2}{|c|}{ K (\%) } \\
\hline & $2002 / 2003$ & $2003 / 2004$ & $2002 / 2003$ & $2003 / 2004$ & 2002/2003 & 2003/2004 \\
\hline \multicolumn{7}{|c|}{ FYM rates $\left(m^{3} /\right.$ fed $)$} \\
\hline \begin{tabular}{|c|}
10 \\
\end{tabular} & 1.46 & 1.58 & 0.26 & 0.31 & 2.21 & 2.28 \\
\hline 20 & 1.61 & 1.72 & 0.32 & 0.37 & 2.30 & 2.35 \\
\hline 30 & 1.67 & 1.82 & 0.35 & 0.40 & 2.36 & 2.42 \\
\hline L.S.D at $5 \%$ & 0.02 & 0.03 & 0.01 & 0.01 & 0.03 & 0.02 \\
\hline \multicolumn{7}{|l|}{ Bio-fertilizers } \\
\hline Control & 0.98 & 1.10 & 0.26 & 0.31 & 2.24 & 2.31 \\
\hline Microbein & 1.77 & 1.93 & 0.32 & 0.37 & 2.31 & 2.38 \\
\hline Phosphorein & 1.09 & 1.12 & 0.37 & 0.42 & 2.33 & 2.39 \\
\hline Rhizobacterein & 1.89 & 1.99 & 0.29 & 0.33 & 2.27 & 2.32 \\
\hline L.S.D at $5 \%$ & 0.023 & 0.441 & 0.016 & 0.012 & N.S & N.S \\
\hline
\end{tabular}

Similar results were obtained by EL-Masry et al. (2002) on geranium, reported that significant response was observed in N, P and $\mathrm{K}$ contents with Urea + FYM. Sakr (2005) on senna, Abd EL-Latif (2006) on sage and Massoud (2007 b) on Ocimum basilicum, stated that application of cattle manure gave significant differences in the herb N, P and K content.

\section{C.2.2. Effect of different bio-fertilizers:}

As shown in Table (16) the inoculating of isabgol with Rhizobacterein bio-fertilizer gave the highest values of nitrogen percentage (1.89 and 1.99 $\%)$, while Phosphorein inoculating recorded the highest phosphorus (0.37 and $0.42 \%)$ and potassium (2.33 and $2.39 \%)$ in the two seasons respectively. marjoram.

The results were agreed with those obtained by Massoud (2007 a) on 


\section{C.2.3 Effect of interaction between FYM and bio-fertilizers:}

The results presented in Table (17) indicated that all interaction treatments affected in the $\mathrm{N}, \mathrm{P}$ and $\mathrm{K}$ percentages.

The high FYM dose combined with Rhizobacterein inoculating gave the highest percentages of $\mathrm{N}(1.99$ and $2.13 \%)$, while the same dose combined with Phosphorein inoculating gave the highest of $\mathrm{P}(0.43$ and 0.46 $\%)$ and potassium (2.40 and $2.48 \%$ ) in the two seasons respectively.

On the other hand, the plants received the low FYM dose without biofertilizers gave the least values of nitrogen $(0.88$ and $1.00 \%)$, phosphorus $(0.22$ and $0.27 \%)$ and potassium (2.15 and $2.25 \%)$ in the two seasons respectively. The differences were non-significant in both seasons.

Table (17): Effect of interaction between farmyard manure (FYM) and bio-fertilizers on dry leaves $\mathrm{N}, \mathrm{P}$ and $\mathrm{K}$ percentages of Plantago ovata Forsk during the two seasons of 2002/03 and 2003/04.

\begin{tabular}{|c|c|c|c|c|c|c|c|}
\hline \multirow{2}{*}{\multicolumn{2}{|c|}{ Treatments }} & \multicolumn{2}{|c|}{ N (\%) } & \multicolumn{2}{|c|}{$\mathbf{P}(\%)$} & \multicolumn{2}{|c|}{ K (\%) } \\
\hline & & $2002 / 2003$ & $2003 / 2004$ & $2002 / 2003$ & $2003 / 2004$ & $2002 / 2003$ & $2003 / 2004$ \\
\hline \multicolumn{8}{|c|}{ FYM $\left(m^{3} /\right.$ fed $)$} \\
\hline & Control & 0.88 & 1.00 & 0.22 & 0.27 & 2.15 & 2.25 \\
\hline \multirow{3}{*}{1} & Microbein & 1.65 & 1.80 & 0.27 & 0.31 & 2.23 & 2.30 \\
\hline & Phosphorein & 0.91 & 1.04 & 0.32 & 0.37 & 2.26 & 2.31 \\
\hline & Rhizobacterein & 1.72 & 1.80 & 0.25 & 0.29 & 2.19 & 2.26 \\
\hline \multirow{4}{*}{20} & Control & 0.97 & 1.08 & 0.28 & 0.32 & 2.26 & 2.32 \\
\hline & Microbein & 1.81 & 1.92 & 0.33 & 0.38 & 2.32 & 2.38 \\
\hline & Phosphorein & 1.02 & 1.12 & 0.36 & 0.42 & 2.33 & 2.38 \\
\hline & Rhizobacterein & 1.96 & 2.04 & 0.30 & 0.34 & 2.28 & 2.33 \\
\hline \multirow{5}{*}{30} & Control & 1.08 & 1.21 & 0.29 & 0.35 & 2.31 & 2.36 \\
\hline & Microbein & 1.86 & 2.06 & 0.36 & 0.41 & 2.38 & 2.45 \\
\hline & Phosphorein & 1.16 & 1.27 & 0.43 & 0.46 & 2.40 & 2.48 \\
\hline & Rhizobacterein & 1.99 & 2.13 & 0.32 & 0.38 & 2.34 & 2.37 \\
\hline & L.S.D at $5 \%$ & N.S & N.S & N.S & N.S & N.S & N.S \\
\hline
\end{tabular}

It can be recommended that, the application of farmyard manure at $20 \mathrm{~m}^{3} / \mathrm{fed}$ combined with Microbein for the best results of growth, seed yield and mucilage content. Also, the application of farmyard manure at $20 \mathrm{~m}^{3} / \mathrm{fed}$ combined with Phosphorein resulted in the heaviest 1000 seed weight. It may be noted that these treatments minimize the pollution of the agricultural environments.

\section{REFERENCES}

Abd El-Latif, E.S.M. (2006). Effect of chemical, organic fertilizers and spraying with active dry yeast on growth, oil production and plant constituents of sage (Salvia officinalis, L.) plant. M.Sc. Thesis, Fac. of Agric., Cairo Univ., Egypt.

Abd El-Latif, T.A. (2002). Effect of organic manure and bio-fertilizer on caraway plants (Carum carvi, L.). J. Agric. Sci. Mansoura Univ., 27(5): 3459-3468.

Abd El-Raouf, R.M.S. (2001). Production of sweet basil (Ocimum basilicum L.) in the new reclaimed lands under different levels of bio-fertilizers and plant densities. M.Sc. Thesis, Fac. of Agric., Ain Shams Univ., Egypt. 
Hamza, A. M. et al.

Abdel-Kader, Hesham, H. and Nawal G. Ghaly (2003). Effects of cutting the herb and the use of Nitrobein and Phosphorein associated with mineral fertilizers on growth, fruit and oil yields and chemical composition of the essential oil of coriander plants (Coriandrum sativum L.). J. Agric. Sci., Mansoura Univ., 28(3): 2161-2171.

Ahmed, M.S.M. (2005). Okra fresh and seed yield response to biological, organic, mineral fertilization and some other culture practice. Ph.D. Thesis, Fac. of Agric., Assiut Univ., Assiut, Egypt.

Attia, F.A. and Saad, O. A. O. (2001). Bio-fertilizers as partial alternative of chemical fertilizer for Catharanthus roseus. J. Agric. Sci., Mansoura Univ., Egypt, 26(11): 7193-7208.

Bhaskar, S.; Kumar, T.V.; Shivananda, T.N.; Arun, M.N.; Janardhan, G. and Ramachandra, C. (2001). Effect of farmyard manure, nitrogen levels and its method of application on scented geranium (Pelargonium graveolens). Journal of Medicinal and Aromatic Plant Sciences, 23(3): 388-391.

Black, C.A. (1965). Methods of soil analysis, Part2. Amer. Soc. of Agric. [NC] Publisher, Madison, Wisconsin.

Cochran, W.G. and G.W.Cox (1957). Experimental Designs. $2^{\text {nd }}$ Ed. John Wiley and Sons. In New York, USA, 595.

Davies, J.; Dettmar, P. and Hoare, R. (1998). Efficacy of ispaghula husk in the treatment of premenstrual constipation-type symptoms. Nutrition and Food Science, 6(11 ref.): 335-337.

Deters, A.M.; Schroder, K.R.; Smiatek, T. and Hensel, A. (2005). Ispaghula (Plantago ovata) seed husk polysaccharides promote proliferation of human epithelial cells (skin keratinocytes and fibroblasts) via enhanced growth factor receptors and energy production. Planta Medica, 71(1): 33-39.

Eid, M.I. and El-Ghawwas, E.O. (2002). Study on the responsibility of marjoram plant to bio-fertilizer in sandy soil.

Eisa, A. (2004). Effect of some bio-fertilizer on salvia plants. Ph.D. Thesis, Fac. Agric. Mansoura Univ., Egypt.

El-Fawakhry, F.M. and H.F. El-Tayeb (2004). Effect of bio-fertilizer and mineral nitrogen on growth and flowering of Euphorbia pulcherrima, Willd. J. Agric. Sci. Mansoura Univ., 29(11): 6483-6490.

El-Gamal, Seham, M.A. (2000). Influence of varied NPK fertilization and different sowing dates on growth, seed production and active constituent of plantago plants. M.Sc. Thesis, Mansoura Univ., Egypt.

El-Ghawwas, E.O. (2002). Studies on the effect of some organic fertilizers on Nigella sativa, L. Plants. Egypt. J. Appl. Sci., 17(6): 325-344.

El-Ghawwas, E.O.; M.A. Eid and S.M. Mohammed (2002). Effect of different levels of organic manures and plant distances on fennel (Foeniculum vulgare, Miller) plant. Egypt. J. Appl. Sci., 17(3): 198-219.

El-Kramany, M.F.; Ahmed, M.K.; Bahr, A.A. and Kabesh, M.O. (2000). Utilization of bio-fertilizers in field crop production. Egypt. J. Appl. Sci., 15(11): 137.

El-Mahdy, A.R. and El-Sebaiy, L.A. (1984). Preliminary studies on the mucilages extracted from okra fruits, taro tubers, Jew's mellow leaves and fenugreek seeds. Food Chemistry 14: 237-249. 
El-Mahrouk, E.M.A. (2000). Using bio-fertilizers for production of the flowers and ornamental plants. Review Article, Fac. Agric., Kafer El-Sheikh, Tanta Univ.

El-Masry, M.H.; Afify, M.M. and Dahab, A.A. (2002). Response of geranium plants (Pelargonium graveolens L.) grown in sandy soil, to different sources of nitrogen and farmyard manure (FYM). $2^{\text {nd }}$ Inter. Conf. Hort. Sci., 10-12 Sept. 2002, Kafr El-Sheikh, Tanta Univ., Egypt.

Gomez, K.A. and A.A. Gomez (1984). Statistical Procedures. Agric. Res., $2^{\text {nd }}$ Ed. John Wiley and Sons, Inc, New York, USA.

Hafez, Y.A.M. (2003). Effect of sow spacing, nitrogenous and biofertilization treatments on growth, yield and chemical composition of Borago officinalis L. Ph.D. Thesis, Fac. Agric., Fayoum, Cairo Univ., Egypt.

Ibrahim, Z.T.Z. (2000). Effect of some cultural practices on growth and chemical composition of some medicinal plants under conditions of north Sinai. Ph.D. Thesis, Fac. Agric. Kafr El-Sheikh, Tanta Univ.

Jackson, M.L. (1967). "Soil chemical analysis advanced course"., Puble, by the auther, Dept. of soils, Wise Univ., Madison 6, Wishensen, USA.

Jamwal, S.; Dhar, M.K. and Kaul, S. (1998). Male sterility in Plantago ovata Forsk. Current Science, 74(6): 504-505.

Kandeel, Y.R.; Nofal, E.S.; Menesi, F.A.; Reda, K.A.; Taher, M. and Zaki, Z.T. (2001). Effect of some culture practices on growth and chemical composition of Foeniculum vulgare. Mill. Proc. Fifth Arabian Hort. Conf., Ismailia, Egypt, March, 24-28, pp. 61-72.

Langmead, L. and Rampton, D.S. (2001). Review article: herbal treatment in gastrointestinal and liver disease-benefits and dangers. Alimentary Pharmacology and Therapeutics, 15(9): 1239-1252.

Mahfouz, S.A.S. (2003). Effect of bio-fertilization on growth and oil production of marjoram (Majorana hortensis, L.) Moench plant. Ph.D. Thesis, Fac. of Agric., Cairo Univ., Egypt.

Marlett, J.A.; Kajs, T.M. and Fischer, M.H. (2000). An unfermented gel component of psyllium seed husk promotes laxation as a lubricant in humans. American Journal of Clinical Nutrition, 72(3): 784-789.

Massoud, Hekmat Y.A. (2007 a). Effect of mineral and bio-phosphate fertilization on the growth, essential oil productivity and chemical composition of marjoram plant. J. Agric. Sci. Mansoura Univ., 32(2): 1293-1308.

Massoud, Hekmat Y.A. (2007 b). Evaluation of some varieties of Ocimum basilicum $\mathrm{L}$. and their response to some organic manures. J. Agric. Sci. Mansoura Univ., 32(4): 2701-2718.

Massoud, Hekmat, Y.; H.H. Abdel-Kader; T.A.T. Abd El-Latif and Manal M. Meligy (2004). Effect of bio and mineral fertilizers on the production of thyme (Thymus vulgaris, L.) plant. J. Agric. Sci. Mansoura Univ., 29(10): 5751-5762.

Mohamed, M.A. (2003). Taxonomical and physiological studies on periwinkle plants. Ph.D. Thesis, Fac. Agric., Cairo Univ., Egypt.

Nofal, E.S.; Kandeel, Y.R.; Menesi, F.A.; Reda, K.A.; Taher, M. and Zaki, Z.T. (2001). Effect of some cultural practices on growth and chemical composition of Ammi visnaga. Proc. of the fifth Arabian Horticulture Conference, Ismailia, Egypt, March 24-28, 51-60. 
Hamza, A. M. et al.

Peter Burgksi, A.V. (1968). Hand Book of Agronomic Chemistry. Kolas Publishing Hause, Moscow, Russian : pp. 29-86.

Pregle, E. (1945). "Quantitative organic micro-analysis", Ed. I. Chudrial, London.

Rodriguez-Cabezas, M.E.; Galvez, J.; Camuesco, D.; Lorente, M.D.; Concha, A.; Martinez-Augustin, O.; Redondo, L. and Zarzuelo, A. (2003). Intestinal anti-inflammatory activity of dietary fiber (Plantago ovata seeds) in HLA-B27 transgenic rats. Clinical Nutrition, 22(5): 463-471.

Sakr, W.R.A.S. (2005). Effect of organic and bio-fertilization on growth and active constituents production of senna plants. Ph.D. Thesis, Fac. of Agric., Cairo Univ., Egypt.

Tomar, R.K.S.; K.N. Kamdeo and J.S. Raghu (1996). Efficacy of phosphate solubilizing bacteria bio-fertilizer with phosphorus on growth and yield of gram (Cicer arietinum). Indian J. Agro., 41(3): 412-415.

Yadav, R.D.; Keshwa, G.L. and Yadav, S.S. (2004). Effect of integrated use of FYM, urea and sulphur on growth and yield of isabgol (Plantago ovata). Soils and Fertilizers Abst., 67(6): 1265

Yousef, A.E.A. (2005). Comparison study between bio and chemical fertilizer on lemon-balm plants (Melissa officinalis, L.). Ph.D. Thesis, Fac. Agric. Mansoura Univ., Egypt.

Yuonis, S.I.; Nawal, G. Ghaly and Shadia, K.A. (2004). Effect of FYM and Planting space on the vegetative growth, active ingredient and chemical composition of Ammi visnaga, L. J. Agric. Sci., Mansoura Univ., 29(4): 1985-1993.

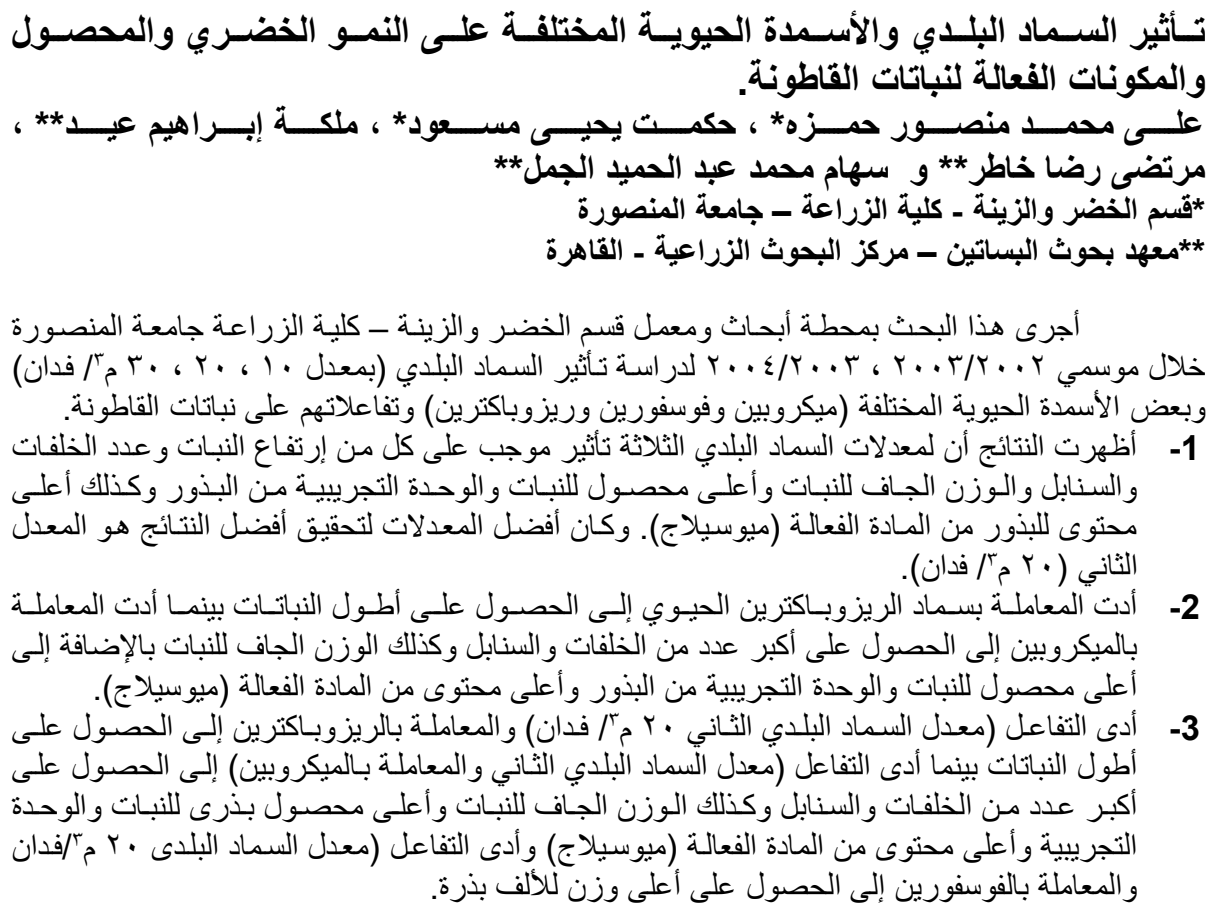

